To Maega | Jurnal Pengabdian Masyarakat

Agustus-2021, Vol. 4, No. 2, hal 124-133.

$\operatorname{ISSN}(P): 2622-6332 ; \operatorname{ISSN}(E): 2622-6340$

http://www.ojs.unanda.ac.id/index.php/tomaega

\title{
Bimbingan Belajar Kimia Bagi Siswa SMA Yang Berdomisili Di Penfui-Binilaka Kupang
}

\author{
Maria Aloisia Uron Leba ${ }^{1 *}$, Faderina Komisia1, Maria Benedikta Tukan ${ }^{1}$ \\ 1 Program Studi pendidikan Kimia, Fakultas Keguruan dan IImu Pendidikan, \\ Universitas Katolik Widya Mandira \\ *Correspondent Email: mariaaloisiauronleba@gmail.com
}

\section{Article History:}

Received: 23-12-2020; Received in Revised: 30-01-2021; Accepted: 06-03-2021

DOI: http://dx.doi.org/10.35914/tomaega.v4i2.572

\begin{abstract}
Abstrak
Bimbingan belajar merupakan salah satu metode belajar dengan cara memberi bantuan berupa penjelasan materi pelajaran secara terstruktur dan perlahan kepada siswa dalam mengatasi kesulitan belajarnya. Kegiatan bimbingan belajar ini bertujuan untuk 1). mengkaji peningkatan pemahaman siswa dalam mempelajari ilmu kimia, 2). mengkaji ketuntasan dari hasil belajar yang diperoleh siswa. Sasaran kegiatan ini adalah tiga siswa SMA kelas X yang tinggal di daerah Penfui - Binilaka, Kupang. Metode pelaksanaan kegiatan ini adalah bimbingan belajar yang meliputi diskusi, penjelasan materi dan latihan soal. Teknik pengumpulan data yang digunakan adalah tes. Data hasil kegiatan ini dianalisis dengan 1). Persamaan N-Gain untuk mengkaji peningkatan pemahaman siswa, 2). Analisis deskriptif untuk mengkaji ketuntasan dari hasil belajar siswa. Hasil analisis menunjukan bahwa 1). Peningkatan pemahaman siswa pada setiap pertemuan tergolong tinggi yang ditunjukan dengan rata-rata nilai $\mathrm{N}$-Gain adalah 0,83, 2). Hasil belajar siswa tergolong tuntas yang ditunjukan dengan rata-rata ketuntasan dari hasil belajar siswa adalah 76,02\%.
\end{abstract}

Kata Kunci: Bimbingan belajar, kimia, hasil belajar, N-Gain, pembelajaran kimia

\begin{abstract}
Tutoring is a learning method that provides assistance in the form of structured and slow explanation of the subject matter to students in solving their learning difficulties. The purpose of this tutoring are to 1). Examines the increase of student understanding in studing chemistry, 2). Examines the completeness of student learning outcomes. The target of this activity are tree high school stutents class $X$ who live in the Penfui - Binilaka. The methods used in this activity are discussion, explanation of the material and exercises. The technique of data collection used was a test. The data of this activity were analized by 1$)$. $N$-Gain equation to assess the increase in student understanding, 2). Descriptive analysis to assess the completeness of student learning outcomes. The analysis results showed that 1). The increase of student understanding at every meeting was high, which was indicated by the average of $N$-Gain value was $0.83,2)$. The learning outcomes of students was complete, which was indicated by the average completeness of student learning outcomes was $76.02 \%$.
\end{abstract}

Keywords: Tutoring, chemistry, learning outcomes, N-Gain, chemistry learning 


\section{Pendahuluan}

Dengan adanya kebijakan dari pemerintah untuk bekerja dari rumah, work from home (WFH) demi memutuskan penyebaran covid-19, lembaga pendidikan dasar hingga Perguruan Tinggi melakukan kegiatan pembelajaran dari rumah secara daring. Tentunya pembelajaran seperti ini memberikan cerita yang berbeda bagi setiap pengguna. Tidak sedikit satuan pendidikan yang menjalankan pembelajaran dengan cara pemberian tugas dengan menggunakan aplikasi whatsapp. Siswa diberikan bahan ajar atau informasi sumber belajar untuk belajar sendiri. Siswa juga diberikan soal-soal kemudian mereka mencari sumber belajar dan berinteraksi dengan sumber belajar tersebut dalam menyelesaikan soal-soal yang diberikan.

Pembelajaran seperti yang diuraikan diatas merupakan pembelajaran yang memberikan ruang bagi siswa untuk berusaha dan menemukan pengalaman belajarnya sendiri. Sesungguhnya pembelajaran seperti ini sangat berguna dalam meningkatkan daya ingat dan pemahaman terhadap pembelajaran karena siswa diberi kesempatan seluas-luasnya untuk mencaritahu, memahami, menjelaskan, dan menyelesaikan persoalannya (problem solving) secara aktif (Nodzinscz \& Ciesla, 2014; Didiharyono \& Qur'ani, 2019). Namun perlu disadari pula bahwa dalam suatu kelas karakteristik dan kemampuan setiap siswa dalam menerima materi pelajaran berbeda (Andayani dkk, 2014). Metode seperti ini sangat baik bagi siswa yang berkemampuan baik dan rasa ingin tahu yang tinggi sehingga dapat menyelesaikan pembelajarannya secara lancar. Namun harus dipikirkan bahwa ada pula siswa-siswa yang kesulitan belajar dengan metode pembelajaran seperti ini. Siswa-siswa yang kesulitan belajar harus membutuhkan bimbingan (Rozak dkk, 2018).

Bimbingan belajar sangat diperlukan terutama di sekolah. Menurut pendapat Prayitno dan Amti (1999) dalam Andayani dkk (2014), siswa yang kurang berhasil dalam belajar belum tentu semata-mata disebabkan karena rendahnya inteligensi siswa tetapi karena siswa belum mendapatkan bimbingan yang memadai. Kurang berhasilnya siswa dalam belajar disebabkan pula karena siswa kurang bersemangat, tidak konsentrasi serta waktu belajar yang tidak teratur (Erica dan Lesmono, 2019). Bimbingan belajar dimaknai sebagai suatu proses belajar berupa memberi bantuan penjelasan dalam mengatasi masalah belajar siswa dan untuk mengoptimalkan hasil belajarnya (Fiah dan Purbaya, 2016; Prasetya dkk, 2013). Bimbingan belajar dilakukan dengan cara memberi penjelasan secara terstruktur dan perlahan yang disesuaikan dengan kemampuan dan daya tanggap siswa. Melalui bimbingan belajar, siswa dapat memperoleh penjelasan tambahan terutama pada materi yang membutuhkan penjelasan yang memadai dan terstruktur.

Ilmu kimia merupakan ilmu pengetahuan yang berkaitan dengan konsep tentang komposisi penyusun suatu materi, struktur dan sifat materi, perubahan materi, serta dinamika dan energetika yang terlibat didalamnya. Konsep-konsep ini berkaitan dengan simbol-simbol dan rumus kimia yang abstrak serta perhitungan-perhitungan yang cukup rumit. Hampir semua topik pembelajaran ilmu kimia membutuhkan penjelasan dan 
bimbingan guru. Ada banyak konsep yang harus dijelaskan secara terstruktur oleh guru terutama konsep-konsep dasar dan prosedural. Dalam pembelajaran kimia SMA kelas $\mathrm{X}$, topik yang dibahas merupakan konsep-konsep yang menjadi dasar dalam mempelajari ilmu kimia pada tingkat selanjutnya. Topik yang dipelajari pada tingkat ini berkaitan dengan simbol, rumus kimia, reaksi kimia dan persamaan reaksi yang cukup abstrak. Unsur dan senyawa merupakan konsep yang paling mendasar dalam ilmu kimia. Dengan demikian konsep ini harus tersampaikan dengan baik kepada siswa.

Kegiatan ini bertujuan untuk membatu meningkatkan pemahaman siswa terhadap ilmu kimia. Dalam kegiatan ini diberikan bimbingan belajar kelompok kepada tiga siswa SMA Katolik St. Carolus kelas X yang berdomisili di daerah Penfui - Binilaka. Materi bimbingan yang diberikan di dasarkan pada pokok bahasan yang sedang dipelajari di sekolah.

SMA Katolik St. Carolus merupakan salah satu sekolah swasta yang berlokasi di Kelurahan Penfui. Siswa-siswa di SMA ini berasal dan atau berdomisili di daerah Penfui, Naimata, Binilaka, Oesapa, Oeltua dan Baumata. Sebagaian besar siswasiswanya dengan latarbelakang ekonomi keluarga menengah ke bawah. Selama masa WFH, SMA ini melaksanakan pembelajaran secara daring dengan menggunakan media whatsapp. Berdasarkan wawancara dengan mitra yakni siswa-siwa kelas X SMA Katolik Sint. Carolus yang berdomisili di sekitar dareah Penfui-Binilaka, kegiatan pembelajaran yang berlasung di sekolahnya saat ini adalah pembelajaran dan pemberian tugas melalui grup whatsapp dan google class room. Dari wawancara ini diketahui bahwa untuk memahami konsep ilmu kimia mereka membutuhkan beberapa kali penjelasan dan bimbingan dari gurunya. Selain itu mereka lebih menyukai kegiatan pembelajaran tatap muka karena ada penjelasan dari guru hingga mereka memahami materi yang dibahas dibandingkan saat in i yang hanya melalui whatsapp dan google class room. Saat ini mereka harus membaca sendiri dan menyelesaikan tugas yang diberikan. Apabila ada hal yang tidak dipahami mereka mengerjakan tugasnya seadanya saja. Selain itu tidak ada umpan balik apakah tugas yang telah dikerjakan sudah betul atau belum, dimana letak kesalahannya dan yang seharusnya seperti apa. Selain itu tidak semua mereka memiliki handphone yang bisa dipakai untuk pembelajaran daring.

Berdasarkan uraian di atas tim pengabdian masyarakat dari program studi pendidikan kimia Universitas Katolik Widya Mandira melakukan kegiatan bimbingan belajar pada matapelajaran kimia kepada siswa-siswa kelas X SMA Katolik St. Carolus Penfui yang berdomisili di daerah sekitaran Penfui-Binilaka.

\section{Metode}

Metode dalam mengimplementasikan kegiatan pengabdian ini adalah bimbingan belajar atau tutorial. Kegiatan ini diawali dengan wawancara tentang materi kimia yang diperoleh di sekolah serta kesulitan-kesulitan yang dialami siswa. Selanjutnya siswa diberi bimbingan belajar dan latihan berdasarkan kebutuhannya yakni terkait materimateri yang belum dipahami dengan baik. Kegiatan bimbingan yang dilakukan adalah 
pada pokok bahasan tentang materi dan perubahannya dengan menekankan pada aspek kontekstual.

Kegiatan ini dilaksanakan di RT 1 dan RT 18 Dusun Binilaka Desa Oeltua kecamatan Taebenu Kabupaten Kupang pada tanggal 4 hingga 25 September 2020. Kegiatan ini dilakukan satu kali setiap minggu yakni pada setiap hari Jumad. Sasaran kegiatan ini adalah siswa kelas X SMA Katolik St. Carolus yang berdomisili di daerah Binilaka yakni sebanyak tiga siswa. Ketiga siswa ini adalah siswa kelas $\mathrm{X}$ bidang minatan IPS yang mendapat mata pelajaran kimia. Mereka dipilih karena baru pertama mempelajari ilmu kimia dan harus mengikiti pembelajaran secara daring akibat pandemi covid-19. Kondisi ini membuat mereka kesulitan dalam mempelajari dan memahami ilmu kimia. Meskipun mereka bukan termasuk dalam kelas bidang minatan IPA namun beberapa pengetahuan tentang ilmu kimia tentunya akan berguna bagi kehudupan mereka di masa yang akan datang (Brady dkk., 2012:2)

Teknik pengumpulan data yang digunakan adalah wawancara, observasi dan tes. Wawancara digunakan untuk mengumpulkan informasi awal tentang pemahaman siswa terhadap materi yang akan dipelajari. Observasi digunakan untuk mengobservasi sikap siswa selama melakukan praktikum sederhana. Tes digunakan untuk:

1. Mengetahui peningkatan pemahaman siswa pada setiap pertemuan Untuk mengetahui peningkatan pemahaman siswa pada setiap pertemuan diberikan tes yang berisikan soal-soal dari materi pada setiap sesi bimbingan. Data yang diperoleh dianalisis secara kuantitatif dengan menggunakan persamaan N-Gain (Lestari dkk, 2015):

$$
\mathrm{N}_{- \text {Gain }}=\frac{\text { Skor Posttest-Skor Pretest }}{\text { Skor maksimum ideal-skor Pretest }}
$$

Nilai N-Gain yang diperoleh ditafsirkan berdasarkan kriteria pada Tabel 1.

Tabel 1. Kriteria Rentang Nilai N-Gain

\begin{tabular}{cc}
\hline Nilai N-gain & Kriteria \\
\hline N-Gain $\geq 0.70$ & Tinggi \\
$0.30<$ N-Gain $<0.70$ & Sedang \\
N-Gain $\leq 0.30$ & Rendah \\
\hline
\end{tabular}

2. Mengetahui ketuntasan hasil belajar secara keseluruhan setelah selesai bimbingan

Untuk mengetahui ketuntasan hasil belajar setiap siswa sec ara keseluruhan dari bimbingan belajar ini, diberikan soal-soal tes yang mencakup keseluruhan materi. Data hasil tes setelah bimbingan belajar dianalisis dengan rumus (Trianto, 2008): 


$$
\begin{gathered}
\mathrm{P}=\frac{\text { jumalah skor yang diperoleh }}{\text { skor maksimum }} .100 \% \\
\begin{array}{l}
\text { Keterangan: } \\
\mathrm{P}: \text { ketuntasan hasil belajar }(\%)
\end{array}
\end{gathered}
$$

Siswa dikatakan tuntas belajarnya apabila ketuntasan dari hasil belajar yang diperoleh siswa $\geq 75 \%$ dan suatu kelas dikatakan tuntas apabila ketuntasan dari hasil belajar yang diperoleh siswa dalam kelas mencapai $\geq 85 \%$ (Trianto, 2008).

\section{Hasil dan Pembahasan}

Kegiatan pengabdian masyarakat yakni bimbingan belajar kimia bagi siswa SMA Katolik Sint. Carolus Kupang kelas X yang berdomisili di daerah Penfui dan Binilaka telah selesai dilaksanakan oleh tim pengabdian masyarakat Program Studi Pendidikan Kimia Universitas Katolik Widya Mandira. Pokok bahasan pertama yang dipelajari dalam kegiatan bimbingan belajar ini adalah materi dan perubahannya.

Berdasarkan wawancara tim pelaksana dengan mitra yakni ketiga siswa yang mengikuti kegiatan bimbingan belajar ini, ternyata sebagian besar materi belum dipahami dengan baik dari pembelajaran secara daring di sekolah. Dengan demikian kegiatan bimbingan belajar dilakukan secara keseluruhan pada pokok bahasan materi dan perubahannya yang mencakup unsur, senyawa, campuran dan perubahan materi. Dalam kegiatan bimbingan belajar ini cara penyampaian materi disesuaikan dengan gaya belajar siswa. Penyampaian bahan pelajaran dilakukan dengan menonjolkan aspek kontekstual yaitu mengaitkan konsep yang dibahas dengan konteks dunia nyata yang dialami siswa sehari-hari. Hal ini disebabkan karena hampir semua aspek kehidupan kita setiap hari berkaitan erat dengan ilmu kimia (Brady, dkk., 2012:2, Rahmawati dkk., 2019).

Pada pertemuan pertama dibahas tentang unsur, senyawa dan campuran. Dalam bimbingan belajar ini agar siswa dapat mengembangkan pengetahuannya materi pelajaran dan contoh-contoh dari unsur, senyawa dan campuran diambil dari bahanbahan yang telah dikenal, digunakan dan ada di wilayah Nusa Tenggara Timur khususnya Kupang. Pada pokok bahasan tentang unsur diperkenalkan berbagai unsur serta lambang unsur seperti yang terdapat dalam tabel periodik unsur. Adapun contohcontoh unsur diantaranya cuprum atau tembaga $(\mathrm{Cu})$ pada kebel listrik, aluminium (Al) pada alat masak aluminium, Ferum (Fe) atau besi berupa batangan besi, aurum atau emas $(\mathrm{Au})$ pada perhiasan emas, carbon (C) yang terdapat pada arang dan isi pensil. Demikian pula senyawa, contoh-contoh senyawa berupa kalsium oksida $(\mathrm{CaO})$ yang ada sebagai kapur siri yang biasa dimakan bersama siri dan pinang oleh orang Timor, NTT, Natrium klorida $(\mathrm{NaCl})$ yang dikenal sebagai garam dapur, asam asetat $\left(\mathrm{CH}_{3} \mathrm{COOH}\right)$ yang dikenal sebagai cuka, Natrium bikarbonat $\left(\mathrm{NaHCO}_{3}\right)$ yang dikenal sebagai soda kue. 
Demikian pula dengan campuran. Diberikan contoh campuran baik campuran homogen maupun heterogen seperti air laut, sirup, es buah, es campur dan lain-lain. Ketika diberikan contoh-contoh dari konsep yang dipelajari dengan konteks dunia nyata siswa, mereka sangat antusias menyebutkan contoh-contoh lain yang sejenis dan aktif bertanya mengenai zat-zat penyusun dari bahan-bahan lainnya yang telah dikenalinya. Pembelajaran dengan menekankan aspek kontekstual seperti ini dapat membatu siswa berpikir dan menghubungkan ilmu pengetahuan yang dipelajarinya dengan penerapan ilmu tersebut dalam kehidupannya (Artini dkk., 2019). Dengan demikian pembelajaran kontekstual diharapkan dapat meningkatkan pemahaman kosep siswa (Afriani, 2018). Antusias siswa selama bimbingan belajar ditunjukan dalam Gambar 1.

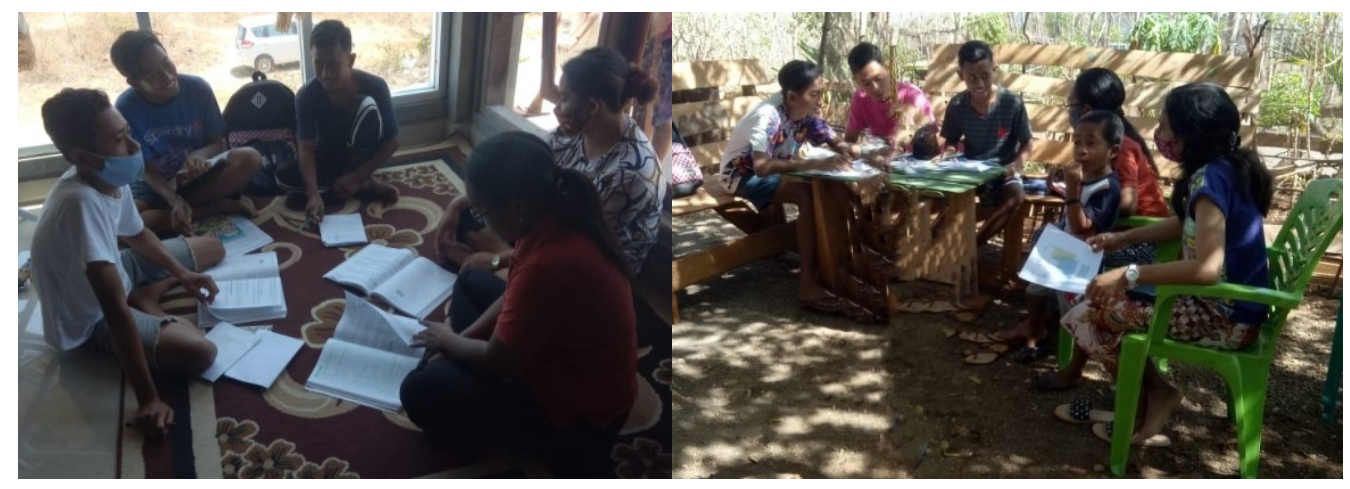

Gambar 1. Proses Bimbingan Belajar

Bimbingan belajar diakhiri dengan pemberian tes. Dari hasil tes ini diketahui bahwa siswa masih kesulitan dalam mengenali nama dan lambang unsur, membedakan antara unsur dan molekul unsur serta masih kesulitan dalam menentukan suatu produk atau bahan yang biasa digunakan sehari-hari atau yang biasa ditemukan secara umum dalam kehidupan sehari-hari ke dalam kelompok unsur, senyawa ataukah campuran. Kesulitan siswa ini disebabkan karena informasi yang diterima belum dipahami dengan baik serta masih kurang latihan. Hal ini sejalan dengan pendapat Prayitno dan Amti (1999) dalam Andayani dkk (2014) bahwa siswa-siswa yang kurang berhasil dalam belajar belum tentu semata-mata disebabkan oleh rendahnya inteligensi siswa tetapi karena siswa belum mendapatkan bimbingan yang memadai. Dengan demikian maka pada pertemuan ke dua kembali dijelaskan lagi pokok bahasan yang sama dengan memberikan penekanan-penekanan pada bagian yang belum dipahami dengan baik serta memperbanyak latihan. Pada akhir petemuan kedua diberikan tes lagi. Hasil tes setelah dua kali bimbingan pada pokok bahasan yang sama menunjukan hasil yang lebih baik dari sebelumnya. Adapun skor tes pada petemuan 1 dan 2 ditampilkan dalam Tabel 2.

Tabel 2 memperlihatkan peningkatan skor setiap siswa pada setiap soal dari pertemuan 1 ke pertemuan 2 . Untuk soal no 1 dan 5 pada pertemuan ke 2, belum dijawab dengan benar oleh ketiga siswa. Soal no 1 berkaitan dengan penentuan lambang unsur dan nama unsur. Berdasarkan jawaban tes diketahui bahwa dua siswa masih salah dalam menentukan lambang unsur natrium $(\mathrm{Na})$. Siswa masih terkecoh dengan lambang 
unsur natrium yakni $\mathrm{Na}$ dengan lambang unsur nitrogen yaitu $\mathrm{N}$. soal no 5 berkaitan dengan pengelompokan zat atau bahan yang digunakan secara umum dalam kehidupan sehari-hari. Dari 12 jenis zat atau bahan yang disajikan baru 1 siswa yang dapat mengelompokannya secara benar sedangkan dua siswa masih bingung mengelompokannya.

Setelah dua kali bimbingan dan latihan, pemahaman siswa pada pokok bahasan unsur, senyawa dan campuran, mengalami peningkatan dengan rata-rata nilai N-Gain 0,83 . Nilai $\mathrm{N}$-Gain yang diperoleh ini tergolong dalam kriteria peningkatan yang tinggi yaitu $\mathrm{N}$-Gain $\geq 0.70$. Hasil ini menunjukan bahwa dengan pembelajaran kontekstual diharapkan dapat meningkatkan pemahaman kosep siswa serta pemahaman ilmu kimia menjadi lebih mudah dan menarik apabila konsep yang diberikan dihubungkan dengan pengetahuan awal dan pengalaman siswa (Andayani dkk, 2014; Leba, 2020). Adapun nilai N-Gain untuk setiap siswa ditampilkan dalam Tabel 3.

Tabel 2. Skor Setiap Siwa Pada Pertemuan 1 dan Pertemuan 2

\begin{tabular}{cccccccc}
\hline \multirow{2}{*}{ No Soal } & \multicolumn{3}{c}{ Skor Setiap Siswa pada Pert. 1 } & \multicolumn{3}{c}{ Skor Setiap Siswa pada Pert. 2 } & Skor \\
\cline { 2 - 6 } & $\mathrm{R}$ & $\mathrm{J}$ & $\mathrm{F}$ & $\mathrm{R}$ & $\mathrm{J}$ & $\mathrm{F}$ & Idel \\
\hline 1 & 2 & 4 & 6 & 7 & 7 & 8 & 8 \\
2 & 5 & 6 & 8 & 8 & 8 & 8 & 8 \\
3 & 3 & 3 & 2 & 4 & 4 & 4 & 4 \\
4 & 5 & 5 & 5 & 5 & 5 & 5 & 5 \\
5 & 7 & 9 & 6 & 10 & 12 & 10 & 12 \\
\hline Total skor & 22 & 27 & 27 & 34 & 36 & 35 & 37 \\
\hline
\end{tabular}

Tabel 3. Nilai N-Gain untuk setiap siswa

\begin{tabular}{ccccccc}
\hline Siswa & $\begin{array}{c}\text { Skor } \\
\text { Pretteast }\end{array}$ & $\begin{array}{c}\text { Skor } \\
\text { posttest }\end{array}$ & $\begin{array}{c}\text { Skor } \\
\text { ideal }\end{array}$ & $\begin{array}{c}\text { Skor } \\
\text { Posttest }- \\
\text { prettest }\end{array}$ & $\begin{array}{c}\text { Skor } \\
\text { Idel- } \\
\text { Prettest }\end{array}$ & $\begin{array}{c}\text { Nilai } \\
\text { N-Gain }\end{array}$ \\
\hline R & 22 & 34 & 37 & 12 & 15 & 0.8 \\
J & 27 & 36 & 37 & 9 & 10 & 0.9 \\
F & 27 & 35 & 37 & 8 & 10 & 0.8 \\
\hline \multicolumn{7}{c}{ Rata-rata } \\
\hline
\end{tabular}

Pada pertemuan ke tiga diberikan bimbingan pada pokok bahasan tentang materi dan perubahan materi baik secara teori maupun praktikum. Untuk pokok bahasan ini ketiga siswa dapat mengikutinya dengan baik. Dalam kegiatan praktikum sederhana tentang perubahan kimia atau reaksi kimia digunakan bahan-bahan yang sudah dikenali siswa. Dalam percobaan ini akan diamati hasil reaksi yang menjadi cirikhas telah terjadi perubahan kimia. Ciri-ciri tersebut yaitu terjadinya perubahan warna setelah kedua zat dicampurkan, perubahan suhu setelah kedua zat dicampurkan, terbentuknya endapan setelah kedua zat bereaksi dan timbulnya gas atau bau setelah reaksi. Untuk mengamati reaksi yang menyebabkan perubahan warna digunakan larutan detergen dan ektrak 
kunyit, perubahan suhu menggunakan cuka dan kapur siri, terbentuknya endapan menggunakan air kapur yang ditiup, dan timbulnya gas menggunakan cuka dan soda kue. Berdasarkan observasi selama kegiatan praktikum sederhana ini, siswa tampak kagum dan memiliki rasa ingin tahu. Timbulnya perasaan kagum karena mereka tidak pernah mengetahui atau membayangkan bahwa bahan-bahan yang biasa digunakan sehari-hari ternyata dapat digunakan sebagai bahan praktikum dalam memahami atau membuktikan suatu konsep.

Rasa ingin tahu ditunjukkan dari berbagai pertanyaan yang dilontarkan berkaitan dengan percobaan yang dilakukan. Rasa ingin tahu yang tinggi juga ditunjukkan dari keinginan mereka untuk mengulangi percobaan yang sama dan mengamati reaksinya dengan lebih saksama. Mereka sangat senang mengikuti pembelajaran serta sangat antusias dalam menyelesaikan soal-soal diskusi yang diberikan. Hal ini menunjukan bahwa pemahaman ilmu kimia menjadi lebih mudah dan menarik bagi siswa apabila konsep yang diberikan dihubungkan dengan pengetahuan awal dan pengalaman siswa (Leba, 2020).

Selanjutnya pada pertemuan ke empat siswa diberikan tes secara keseluruhan mulai dari pertemuan pertama hingga pertemuan ketiga. Adapun hasil belajar siswa secara keseluruhan ditampilkan dalam Tabel 4.

Tabel 4. Hasil Belajar Siswa

\begin{tabular}{cccc}
\hline No soal & \multicolumn{3}{c}{ Kode Siswa } \\
\cline { 2 - 4 } & $\mathrm{R}$ & $\mathrm{J}$ & $\mathrm{F}$ \\
\hline $\mathbf{1}$ & 5 & 9 & 9 \\
\hline $\mathbf{3}$ & 10 & 9 & 9 \\
\hline $\mathbf{4}$ & 5 & 5 & 5 \\
\hline $\mathbf{5}$ & 8 & 8 & 8 \\
\hline $\mathbf{6}$ & 8 & 5 & 4 \\
$\mathbf{7}$ & 4 & 3 & 4 \\
\hline Jumlah skor & 4 & 4 & 4 \\
\hline Skor maksimal & 44 & 43 & 43 \\
\hline Ketuntasan hasil belajar (\%) & 57 & 57 & 57 \\
\hline Rata-rata ketuntasa Hasil & & 75,44 & 75,44 \\
belajar (\%) & & & \\
\hline
\end{tabular}

Berdasarkan Tabel 4, ketuntasan hasil belajar untuk ketiga siswa mencapai lebih besar dari 75\%. Dengan demikian bimbingan belajar yang dilakukan khususnya pada pokok bahasan tentang materi dan perubahannya (unsur, senyawa, campuran dan perubahan materi) dapat menuntaskan hasil belajar siswa karena rata-rata ketuntasan hasil belajar ketiga siswa adalah 76,02 \%. Demikian pula ketuntasan belajar dari kelompok bimbingan belajar ini dikatakan tuntas karena ketuntasan hasil belajar kelompok ini mencapai $\geq 85 \%$ yakni 100\% (Trianto, 2008). Dengan demikian 
bimbingan belajar yang telah dilakukan berhasil membantu siswa dalam mempelajari ilmu kimia khususnya pada pokok bahasan materi dan perubahannya.

\section{Kesimpulan}

Kegiatan ini memberikan dampak yang positif terhadap pemahaman siswa dalam mempelajari ilmu kimia. Hal ini dibuktikan dari rata-rata nilai $\mathrm{N}-\mathrm{Gain}$ yang diperoleh yaitu $\mathrm{N}-$ Gain $\geq 0.70$ yakni 0,83 yang menunjukan kriteria peningkatan yang tinggi. Keberhasilan bimbingan belajar dapat dibuktikan berdasarkan ketuntasan hasil belajar pada pokok bahasan unsur, senyawa, campuran dan perubahan materi dengan rata-rata ketuntasan hasil belajar siswa mencapai 76,02\%.

\section{Ucapan Terimakasih}

Ucapan terimakasih disampaikan kepada Lembaga Penelitian dan Pengabdian Masyarakat Universitas Katolik Widya Mandira yang telah membiayai kegiatan pengabdian masyarakat ini.

\section{Daftar Pustaka}

Afriani, Andri. (2018). Pembelajaran Kontekstual (Contextual teching and learning) dan Pemahaman Siswa. Al-Muta'aliyah. (1)3.

Andayani, Ni Putu Sri Nonik., Sulastri, Made., Sedanayasa, Gede. (2014). Penerapan Layanan Bimbingan Belajar untuk Meningkatkan Prestasi Belajar bagi Siswa yang Mengalami Kesulitan Belajar Siswa Kelas X4 SMA Negeri 1 Sukasada. Jurnal Undiksa Jurusan Bimbingan Konseling. (2)1.

Artini, Diah., Suardana, Nyoman., Wiratini, Made. (2019). Pengaruh Model Pembelajaran Kontekstual Pada Pokok Bahasan Hidrokarbon Terhadap Hasil Belajar Kimia. Jurnal Pendidikan Kimia Undiksha. (3)1, 20-28.

Brady, James E., Jespersen, Neil D., Hyslop, Alison. (2012). Chemistry, sixth Edition. New York : John Wiley and Sons Inc (Wiley).

Didiharyono, D., \& Qur'ani, B. (2019). Increasing Community Knowledge through the Literacy Movement. To Maega: Jurnal Pengabdian Masyarakat, 2(1), 17-24.

Erica, Deni dan Lesmono, Ibnu Dwi. (2019). Pengaruh Bimbingan Belajar Terhadap Prestasi Belajar Siswa (Studi Kasus SMA Mulia Buana Parung Panjang). Nusantara, Jurnal Ilmu Pengetahuan Sosial. (6)1, 51-65.

Fiah, R. El dan Purbaya, A. Putra. (2016). Penerapan Bimbingan Belajar dalam Meningkatkan Hasil Belajar Peserta Didik di SMP Negeri 12 Kota Bandar Lampung Tahun Pelajaran 2015/2016. Konseli. (3)2, 171-184.

Leba, Maria Aloisia Uron dan Nona, Maria Goreti. (2020). Eksperimen Kimia Sederhana. Yogyakarta: Deepublish. 
[ 133 ] Maria Aloisia Uron Leba, dkk / To Maega : Jurnal Pengabdian Masyarakat, Vol.4; No.2; Agustus, 2021

Lestari, Karunia Eka dan Yudhanegara. (2015). Penelitian Pendidikan Matematika. Bandung: PT Refika Aditama.

Nodzinscz dan Ciesla. (2014). Experiment in Teaching and Learning Natural Sciences. Monograph, ISBN 978-83-7271-878-5.

Prasetya, Ignatius Gemilau Ragil., Winarno, Rachmat Djati., Eriany Praharesti. (2013). Bimbingan Belajar Efektif Untuk Meningkatkan Kebiasaan Belajar pada Siswa Kelas VII. Prediksi, Kajian Ilmiah Psikologi. (2)1, 1 - 4.

Rahmawati, Lidia., Supardi, Kasmadi Imam., Sulistyaningsih, Triastuti. (2019). Contextual Teaching and Learning Integrated with Character Education to Improve Student's Motivation and Character in Concentration of Solutions Topic at Pharmacy Vocational School. Journal of Innovative Science Education. (8)3, 239-247.

Rozak, Abdul., Fathurrochman, Irwan., Ristianti, Dina Hajja. (2018). Analisis pelaksanaan Bimbingan Belajar dalam Mengatasi Kesulitan Belajar Siswa. Journal of Education and Instruction.(1)1, 10-20.

Trianto. (2008). Mendesain Pembelajaran Kontekstual (Contextual Teaching and Learnning) di Kelas. Jakarta: Cerdas Pustaka Publisher. 